\title{
TUBERCULOSIS MANAGEMENT - SOME ASPECTS OF THE ROLE OF THE NURSE MANAGER
}

\author{
MAY ELISE HATTINGH (RN, RM, Reg. Psych. N and Dip. Com. H.N.) \\ ORGANISER OF NURSING SERVICES, DEPARTMENT OF HEALTH, WELFARE AND PENSIONS
}

\section{OPSOMMING}

\begin{abstract}
Tuberkulosebeheer skep 'n uitdaging vir die verpleegadministrateur se bestuursvermoë. Weens haar deeglike kennis van die gemeenskap is sy ' $n$ ideale lid van die tuberkulosebeheerspan.

Eerstens moet streeksomstandighede soos demografiese, maatskaplike en omgewingsfaktore wat die verspreiding van tuberkulose in 'n spesifieke streek bevorder, bepaal word. Die beskikbaarheid van personeel, voorrade, vervoer en fondse moet ook vasgestel word. Hierdie inligting word gebruik om 'n probleemstelling te formuleer.

Die opstel van 'n aksieplan behels interpretasie van beleid, prioriteits- en doelwitbepaling. Prioriteite word deels van die probleemstelling afgelei en deels deur nasionale beleid voorgeskryf. Nasionale prioriteite vir tuberkulosebeheer sluit in motivering, gevalopsporing, buitepasiëntebehandeling en primêre voorkoming deur BCG-inenting.

Die verpleegadministrateur het verantwoordelikhede ten opsigte van die uitvoer van die aksieplan, finansiële beheer en die evaluering van die resultate aan die hand van die doelwitte wat gestel is.
\end{abstract}

\section{BACKGROUND}

$\mathbf{E}$ vidence suggests that the rapid Aspread of tuberculosis began in the early 1920 s when the gold and diamond mines were established. In the late 1940 s when the first two tuberculosis drugs became available it was the doctor who prescribed and administered treatment to the patients. Although public health nurses were present in the field at this stage, they were few and far between and could not contribute much towards tuberculosis management.

During the mid 1950s the doctor screened and prescribed the treatment for the patients in the rural areas. At this stage the public health nurse became more actively involved in the treatment and management of tuberculosis by assisting with screening tests and the administration of treatment as prescribed by the doctor.

The number of doctors at the functional level of tuberculosis management started decreasing during the 1960 s and by the mid-seventies a shortage of doctors working in the field was experienced. This shortage has remained until today. At the same time, however, the number of public health nurses and other nursing categories in the field was increasing and their attention to tuberculosis intensified.

In November 1979 the Department of Health, Welfare and Pensions introduced a National Tuberculosis Policy
Statement and shortly thereafter a National Tuberculosis Treatment Policy. These policy statements were prepared in consultation with leading international tuberculosis specialists.

When written policy is actively implemented it assists the nurse in establishing her role in the community. Policy statements, together with procedure manuals and job descriptions, are essential to define the community health nurse's practice and to legitimise her role. The tuberculosis policies allow the community health nurse to develop her independent professional function. They also pose a challenge for her planning, supervision. administration and general management skills.

\section{TUBERCULOSIS MANAGEMENT BY THE NURSE}

A broad outline of a supervisory community health nurse's role in a health region regarding tuberculosis management is given and only the major aspects highlighted.

\section{ASSESSMENT}

The supervisory community health nurse assesses the regional conditions by taking into consideration the physical, social, psychological and environmental factors that predispose the particular community to tuberculosis. Her intimate knowledge of the area will greatly assist her in this task. Data is collected from records and through consultation, interviews and observation. The type of data required for tuberculosis management could include the following:

\section{Regional conditions}

- population statistics;

- a brief analysis of the demography of the area;

- communication facilities (postal service, telephone etc);

- occupational conditions (type of mines, factories etc);

- socio-economic conditions (income, housing, sanitation etc);

- traditional rites and beliefs;

- nutritional status;

- educational status;

— immunisation status;

\section{Regional assets}

- availability of manpower;

- availability of stocks and equipment;

- availability of transport;

- actual allocation of funds for the service

The data collected should not be the supervisory community health nurse's own interpretation of the tuberculosis situation in her region and to avoid subjectivity the data is checked to ensure that the information is factual and accurate

Problems are identified and grouped as being either actual or potential. A 
written analysis of the problems is compiled from the base-line information. Detail in the problem statement is necessary to ensure that a comprehensive action plan will be devised.

\section{Planning}

The planning phase involves interpretation of policy, determining priorities, setting objectives as well as selecting and recording an action plan. The protocol for planning a tuberculosis service is in a broad sense laid down in the National Tuberculosis Policy, as the national priorities regarding tuberculosis motivation, intensified case finding, supervised treatment and primary protection have been determined.

The supervisory community health nurse now has to apply these priorities to her region while taking into account the data collected and the written problem statement.

On a national basis tuberculosis motivation is of the highest priority and therefore high risk areas are identified, the financial allocation is examined and the priority areas for appointing or increasing tuberculosis motivators are determined.

The case-finding priorities are as follows:

- bacteriological case-finding by culture of the sputum;

- bacteriological case-finding by microscopic examination of the sputum in cases where there is little doubt on clinical examination that the patient is suffering from tuberculosis;

- radiological case-finding by selective $\mathrm{X}$-ray campaigns only where they can be preceded by intensive tuberculosis education and motivation programmes;

- case-finding via contacts of positive cases and via contacts of positive tuberculin reactors.

In consultation with the supervisory medical officer the community health nurse determines which case-finding method would be the most feasible and successful in each identified priority area. A particular method may not be compatible with local conditions in a given area due to, for example, lack of transport, poor road conditions, lack of communication facilities.

The priorities with regard to treatment are to encourage supervised ambulatory/domiciliary treatment for the majority of patients in the Republic and to hospitalise only those cases who are too ill for out-patient treatment. who are domiciled where no out-patient treatment facilities exist and who request hospitalisation. The four national treatment regimes are studied and the costs involved in each established. The data collected for assessment purposes is of infinite value in planning the type of treatment to be used. Using this data the following are ascertained:

- the number of patients to be treated on an out-patient basis for one financial year;

- the number of patients to be hospitalised during one financial year;

- which treatment schedules are to be used in an out-patient service and to what extent.

Under the item of primary protection, the policy introduces a four-dose $\mathrm{BCG}$ regimen to be administered percutaneously to the following:

- all new-borns;

- at three months of age;

- all school-beginners;

- all school-leavers.

The supervisory community health nurse determines the birth-rate, the number of first attendances at childhealth clinics, the number of school-beginners and school-leavers, the financial implications, the amount of $B C G$ vaccine and vaccinating apparatus to be ordered and the amount to be distributed to the various service points.

Priorities with regard to training of nursing personnel in the various aspects of tuberculosis management are also determined and then classified either as informal staff development education or as formal continuing education, taking into account the financial implications of each.

The next phase that the nurse-manager deals with is the setting of objectives. An objective is a clearly defined statement of a desired result that has to be achieved by a set date. The objective should measure output and not input, in other words, it refers to the end result and not to the activities. If the objectives are clearly formulated in terms of outputs and supported with an action plan, it keeps the nurse manager's attention focused on the matter that counts - the end result. Examples of objectives that have been set are:

Tuberculosis motivation: that within a given financial year $30 \%$ of a tuberculosis motivator's contact group will actively respond and report at a service point.

Tuberculosis case-finding: that within a given financial year the ratio of positive to negative sputum results will increase by $15 \%$ (indicating effective, selective case-finding programmes.)

Tuberculosis treatment: that in a given financial year the number of patients on supervised ambulatory/domiciliary treatment will increase by $15 \%$.
Primary protection: that in a given financial year the number of children who have been actively immunised with BCG vaccine will increase by $2 \%$ (the low percentage increase is due to the fact that $80 \%$ of the children in this area are already effectively vaccinated with $\mathrm{BCG}$ and the $2 \%$ increase is the estimated population increase for one year).

In order to get the organisation to work, the supervisory community health nurse must gear the nursing staff into action. This is achieved by compiling an action plan which is defined as being a written statement of the key activities to be performed to achieve the set objectives. Only when each stated objective is accompanied by the key activities necessary to ensure its achievement is the planning process complete The initial plan of action can be modified as more facts, indicating other courses of action, become available Therefore the management team regularly reviews and modifies the plan.

\section{Implementation}

The action plan is usually put into practice in the field by nursing team members and the tuberculosis patient. Today the patient's family and the community are becoming increasingly involved in initiating the implementation of the action plan, for example by a voluntary request for treatment or for information about tuberculosis or by assisting in supervised treatment. There are various ways in which the action plan may be implemented and the management team ensures that the key activities can be carried out with the available resources. Implementation of the action plan is made easier for the nursing team by providing standardised forms and records, good teaching material and flow charts. Examples of flow charts that simplify some aspects of the lengthy National Tuberculosis Policy statements can be seen in:

Figure 1: Bacteriological investigations to be done on new cases.

Figure 2: Bacteriological investigations to be done on old cases (relapse or re-infection).

Figure 3: Investigations and follow-up to be carried out for patients that default.

\section{Evaluation}

The supervisory community health nurse together with the medical officer, the pharmacist and the administrative officer (the tuberculosis management team) evaluates or measures the effectiveness of the action plan on a monthly basis. 
The criteria for measuring effectiveness have been set out in the objectives. All relevent information is collected from the authorities and clinics in the field and compared with the objectives. The team then decides whether the objectives will be achieved, partially achieved or not achieved. The problems that have been found are investigated and the action necessary to alleviate them is decided upon. The very important aspect of controlling the quality of nursing care is carried out in the same manner provided an objective has been set to determine this. If not, quality is controlled by formal individual evaluation.

Financial control is carried out by the assessment of a variety of computerised print-outs. Projections are made to ascertain the expected expenditure by the end of a given financial year for each authority rendering a tuberculosis service in the region. Any over-expenditure or under-expenditure is investigated and corrected to ensure that the allocated funds are not exceeded. The management team also makes provision to curb over-expenditure resulting from practices such as overclaiming on subsidies and hoarding of medicines and vaccines.

Statistical data regarding the epidemiological trends of the various types of tuberculosis are monitored and evaluated regularly. A change in the trend may necessitate a revision of the action plan and/or the objectives.

The community health nurse is the ideal person to become a member of the tuberculosis management team because she has developed an excellent sense of responsibility by being the key member concerned with the health of the community in a specific geographical area. She has the ability to analyse and react to health problems, to foster team-spirit and to stimulate enthusiasm among collegues. Her experience in planning and arranging programmes in her area is invaluable. The future tuberculosis nurse manager needs the skills, abilities and experience of the community health nurse.

\section{REFERENCES}

Hinds, R.B. The art of management by objectives. Management. June 1981

Kleeburg. H.H. Review of the past and present $T B$ situation in South Africa. Paper presented at the National Tuberculosis Conference. Pretoria. June 1979.

Yura, H.; Walsh, M.B. The nursing process. Appleton-Century-Crofts. New York. 1973.

Kratz, C.R. The nursing process. Bailliére Tindall. London. 1979 